\title{
DESIGN AND OPERATION OF THE US WAVE OVERTOPPING SIMULATOR
}

\author{
Jentsje van der Meer ${ }^{1,}$ Chris Thornton ${ }^{2}$ and Steve Hughes ${ }^{3}$
}

\begin{abstract}
Providing necessary levee resiliency requires full-scale modeling of realistic field conditions to evaluate grass cover and various slope armoring alternatives. It is for this reason that a Wave Overtopping Simulator was designed and constructed at Colorado State University, taking into account the experience in the Netherlands. Requirements led to a tailor made machine, three times bigger than the Dutch one. The Simulator is able to simulate any required overtopping duration, for short or long waves and up to overtopping discharges of $200 \mathrm{l} / \mathrm{s}$ per $\mathrm{m}$ and more. Specifications led to a design with a small $6 \mathrm{~m}^{3}$ per $\mathrm{m}$ Simulator, similar to the Dutch one, within a much bigger box and creating a total capacity of $17 \mathrm{~m}^{3}$ per $\mathrm{m}$ width. The calibration led to a procedure to create the correct steering files for the operation of this new Wave Overtopping Simulator.
\end{abstract}

\section{INTRODUCTION}

During Hurricane Katrina in 2005, the most common cause of levee or dike failure was attributed to severe wave overtopping and erosion of the landward/protected side. The levee system is being repaired and strengthen by Task Force Hope to withstand a storm or hurricane event with a probability of occurrence of once per hundred years. A key feature of the new design is assuring that levees have sufficient resiliency to resist hurricane conditions without breaching well beyond the conditions associated with the 100-year storm event. Providing necessary levee resiliency required full-scale modeling of realistic field conditions to evaluate grass cover and various slope armoring alternatives.

Colorado State University was chosen to set-up and perform this kind of testing. They have extensive experience in full-scale testing of slope protection systems under constant flow conditions, like for spillways of hydro power dams. What was lacking was the dynamic behaviour of overtopping waves instead of constant flow.

The Dutch Wave Overtopping Simulator has been a great success since 2007, after four years of testing real dikes or levees against wave overtopping, see Van der Meer et al. (2009, 2010) and Steendam et al. (2010). It is for that reason that Colorado State University was asked to develop a similar machine, but tailor made to specifications given by Task Force Hope. This paper describes the design, construction and operation of this new and improved Wave Overtopping Simulator test facility that is fixed in place instead of being mobile.

\footnotetext{
${ }^{1}$ Van der Meer Consulting BV, P.O. Box 423, 8447 CG, Heerenveen, NL. jm@vandermeerconsulting.nl 2Director, Engineering Research Center, Colorado State University, USA, thornton@engr.colostate.edu 3 Formerly U.S. Army Engineer Research and Development Center, USA, steven.a.hughespe@gmail.com
} 
SPECIFICATIONS FOR THE SIMULATOR LEADING TO DESIGN CRITERIA

\section{Wave and overtopping conditions}

Various wave conditions may occur along the levees around New Orleans. Two typical conditions were selected by Task Force Hope for testing:

$\bullet \mathrm{H}_{\mathrm{s}}=2.4 \mathrm{~m}(8 \mathrm{ft})$ with $\mathrm{T}_{\mathrm{p}}=14 \mathrm{~s}$

$-\mathrm{H}_{\mathrm{s}}=0.9 \mathrm{~m}(3 \mathrm{ft})$ with $\mathrm{T}_{\mathrm{p}}=6 \mathrm{~s}$

Grassed as well as reinforced sections should be tested up to $200 \mathrm{l} / \mathrm{s}$ per m wave overtopping. The two wave conditions have completely different peak periods, which means that the overtopping duration of an overtopping wave depends on the wave condition. Similar overtopping volumes should be released with different overtopping durations. The only way to cope with this requirement was to open the valve of the Simulator to such an extent that the required overtopping duration was met. This is a novelty compared to the Dutch Simulator. The requirement of $200 \mathrm{l} / \mathrm{s}$ per $\mathrm{m}$ as maximum overtopping discharge is about three times larger than the capacity of the Dutch Simulator. With other words: a novel and very large Wave Overtopping Simulator had to be designed.

Levee geometry and wave conditions, including the water level, lead to specific wave overtopping conditions, like mean overtopping discharge, percentage or number of overtopping waves and maximum overtopping volumes. Wave overtopping has been extensively described in the Overtopping Manual (2007), including the calculation program PC-Overtopping and wave overtopping equations are not repeated here.

Table 1 shows some of the overtopping values, taking the wave condition with $14 \mathrm{~s}$ as an example, a straight 1:4 seaward slope and a duration of 1 hour. PCOvertopping was used to calculate the values. Due to the work in the US the original work was performed in imperial units. In this paper, where possible, it was transferred to SI-units, but imperial units had to be used is some locations.

Table 1. Calculations for $H_{m 0}=2.4 \mathrm{~m}(8 \mathrm{ft})$ with $T_{p}=14 \mathrm{~s}$

\begin{tabular}{|c|c|c|c|c|c|c|c|c|c|c|c|c|c|c|}
\hline $\mathrm{Hm} 0=$ & $8 \mathrm{ft}$ & $\operatorname{Hm} 0=$ & \multicolumn{2}{|c|}{$2.44 \mathrm{~m}$} & & input & & & & & & & & \\
\hline $\mathrm{Tp}=$ & $14 \mathrm{~s}$ & $\mathrm{Tm}=\mathrm{Tp} / 1.2=$ & \multicolumn{2}{|c|}{$11.7 \mathrm{~s}$} & & \multicolumn{5}{|c|}{ calculated by PC-Overtopping } & & & & \\
\hline $\operatorname{cota}=$ & 4 & Ru2\%= & \multicolumn{2}{|c|}{$8.04 \mathrm{~m}$} & & & & & & & & & & \\
\hline Duration & 1 hour & $\mathrm{Ru} 2 \%=$ & \multicolumn{2}{|c|}{$26.37 \mathrm{ft}$} & & & & & & & & & & \\
\hline & & Number of waves & \multicolumn{2}{|c|}{309} & & & & & & & & & & \\
\hline & & & & & & & & & & & & & & \\
\hline \multicolumn{3}{|c|}{ Mean overtopping discharge (cfs/ft) } & 0.1 & 0.2 & 0.4 & 0.6 & 0.8 & 1.0 & 1.2 & 1.4 & 1.6 & 1.8 & 2.0 & 4.6 \\
\hline \multicolumn{3}{|c|}{ Mean overtopping discharge (1/s per m) } & 9 & 19 & 37 & 56 & 74 & 93 & 111 & 130 & 149 & 167 & 186 & 425 \\
\hline \multicolumn{3}{|c|}{ Crest freeboard (ft) } & 19.3 & 16.9 & 14.5 & 13.1 & 12.1 & 11.3 & 10.7 & 10.1 & 9.6 & 9.3 & 8.9 & 6 \\
\hline \multicolumn{3}{|c|}{ Crest freeboard PCO (m) } & 5.88 & 5.15 & 4.41 & 3.98 & 3.68 & 3.44 & 3.25 & 3.08 & 2.94 & 2.82 & 2.71 & 1.83 \\
\hline \multicolumn{3}{|c|}{ Percentage of overtopping waves PCO (\%) } & 12.3 & 20.1 & 30.8 & 38.3 & 44.1 & 48.9 & 52.8 & 56.3 & 59.3 & 61.8 & 64.1 & 81.7 \\
\hline \multicolumn{3}{|c|}{ Number of overtopping waves } & 38 & 62 & 95 & 118 & 136 & 151 & 163 & 174 & 183 & 191 & 198 & 252 \\
\hline \multicolumn{3}{|c|}{ Maximum overtopping volume $\left(\mathrm{ft}^{3} / \mathrm{ft}\right)$} & 45 & 64 & 96 & 123 & 148 & 172 & 195 & 218 & 239 & 260 & 280 & 536 \\
\hline \multicolumn{3}{|c|}{ Maximum overtopping volume PCO (1/m) } & 4135 & 5980 & 8935 & 11469 & 13761 & 15998 & 18088 & 20235 & 22233 & 24134 & 26046 & 49838 \\
\hline \multicolumn{3}{|c|}{ Coefficient "0.84" in a } & 0.915 & 0.888 & 0.868 & 0.865 & 0.866 & 0.864 & 0.863 & 0.861 & 0.861 & 0.86 & 0.86 & \\
\hline
\end{tabular}

The non-exceedance probability, $\mathrm{P}_{\mathrm{V}}$, of an overtopping volume per wave as given in the Overtopping Manual (2007), is: 


$$
P_{V}=P(\underline{V} \leq V)=1-\exp \left[-\left(\frac{V}{a}\right)^{0.75}\right]
$$

$$
\text { with: } a=0.84 \cdot T_{m} \cdot \frac{q}{P_{o v}}=0.84 \cdot T_{m} \cdot q \cdot N_{w} / N_{o w}=0.84 \cdot q \cdot t / N_{o w}
$$

Equation 2 shows that the scale parameter a, depends on the overtopping discharge, q, but also on the mean period, $\mathrm{T}_{\mathrm{m}}$, and probability of overtopping, $\mathrm{N}_{\text {ow }} / \mathrm{N}_{\mathrm{w}}$, or which is similar, on the storm duration, $\mathrm{t}$, and the actual number of overtopping waves $\mathrm{N}_{\text {ow }}$. Equation 2 gives the "a"-coefficient to be used to construct the distribution of overtopping waves. The equation contains the factor 0.84 , which actually is only valid for an infinite number of overtopping waves. For a finite number of overtopping waves the factor should be adjusted (increased) by iteration in such a way that the summation of all overtopping volumes is equal to the total discharge over time:

$$
\sum_{i=N w}^{i=1} V_{i}=q t
$$

If this adjustment is not done the summation of volumes will be less than the total overtopping volume calculated from the mean discharge over time. Figure 1 shows the adjustment of this factor 0.84 for a large variety of number of overtopping waves (including Dutch situations).

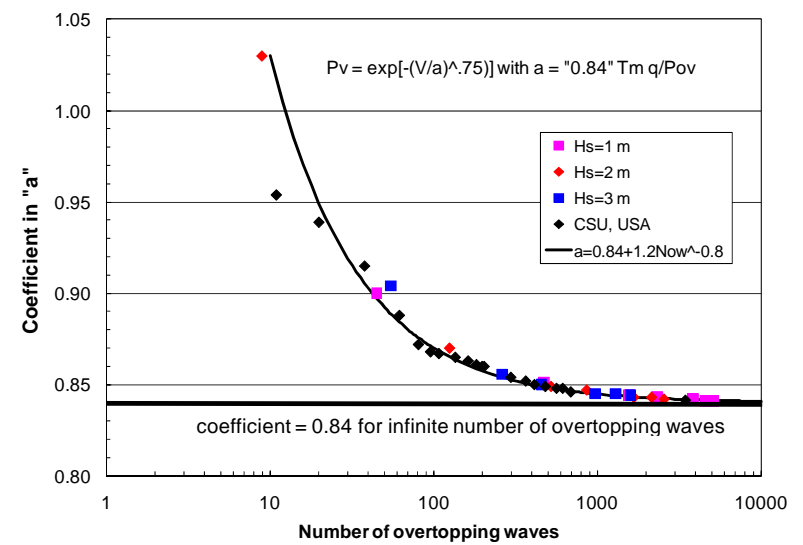

Figure 1. Variation of factor "a" in Equation 2, depending on total number of overtopping waves.

Only if the total number of overtopping waves is in the order of thousand or more the value of 0.84 is reached. For less than 50 overtopping waves the factor is closer to 0.9 . In order to make an easy adjustment of this factor a curve has been fitted through the data points, which can be described by:

$$
\text { factor in "a" (Eq. 2) }=0.84+1.2 \mathrm{~N}_{\mathrm{ow}}^{-0.8}
$$


Maximum size of the Wave Overtopping Simulator

The wave conditions with $\mathrm{H}_{\mathrm{m} 0}=2.4 \mathrm{~m}(8 \mathrm{ft})$ and the long peak period of $14 \mathrm{~s}$ give the largest overtopping volumes, compared to the conditions with a wave height of $0.9 \mathrm{~m}(3 \mathrm{ft}$ ) and a wave period of $6 \mathrm{~s}$. For this condition maximum volumes even reach 25,000 l/m $\left(25 \mathrm{~m}^{3} / \mathrm{m}\right)$, see Fig. 2.

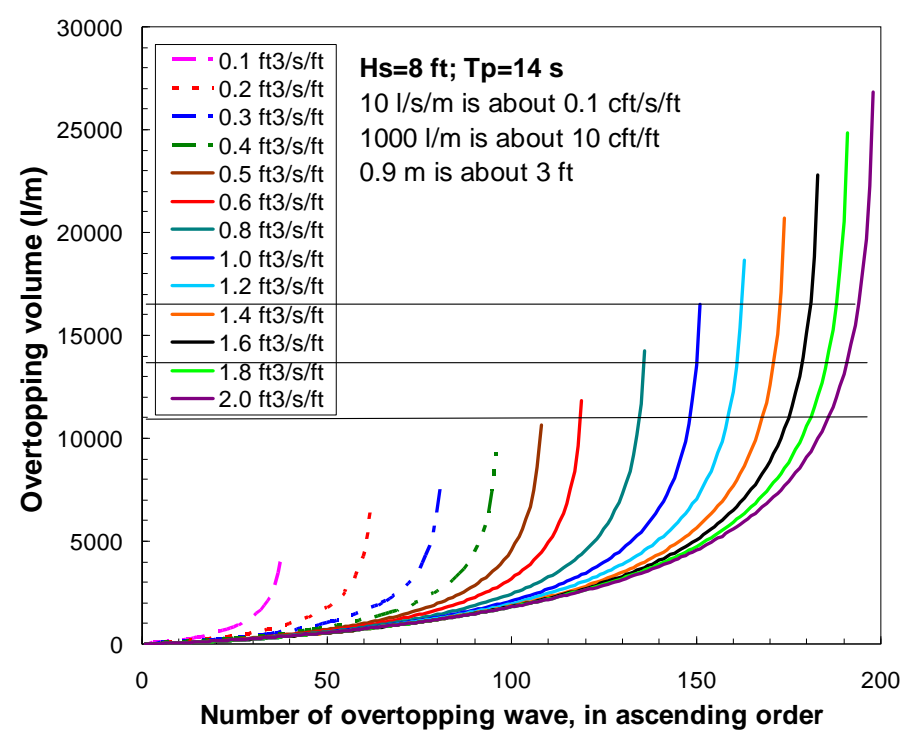

Figure 2. Required distribution of overtopping volumes for $H_{m 0}=2.4 \mathrm{~m} \mathrm{(8ft)}$ with $T_{p}=14 \mathrm{~s}$.

The Dutch Wave Overtopping Simulator has a size of $5.5 \mathrm{~m}^{3} / \mathrm{m}$. This means that, if maximum overtopping volumes of $25 \mathrm{~m}^{3} / \mathrm{m}$ should be realized, the US Simulator should be designed 4 or 5 times larger than the Dutch one. This is practically impossible.

But there is a doubt on the maximum overtopping volumes if they become very large. The physical limit is the water content in an actual wave with the water level close to the crest of a levee. Equations on distributions of overtopping waves do not consider a physical maximum.

Hughes and Nadal (2009) have performed overtopping tests where the water level was even higher than the crest of the levee. These were tests on continuous overflow combined with wave overtopping. They were able to calculate wave by wave overtopping from integration of the flow depth and flow velocity record and they presented the shape factor of the overtopping distribution for each test, which is 0.75 in Eq. 1.

Figure 3 gives Hughes and Nadal's (2009) graph, where bv is the shape factor. The value of bv $=0.75$ for positive crest freeboards has been added to this graph. All of Hughes and Nadal's shape factors are (much) larger than 0.75, which means that the distributions are much gentler. Many values are even 
larger than 2, which means gentler than a Rayleigh distribution. The condition with the water level closest to the crest level $\left(R_{c}=-0.29 \mathrm{~m}\right)$ gives values between 1 and 2 and this is closest to the situation without continuous overflow.

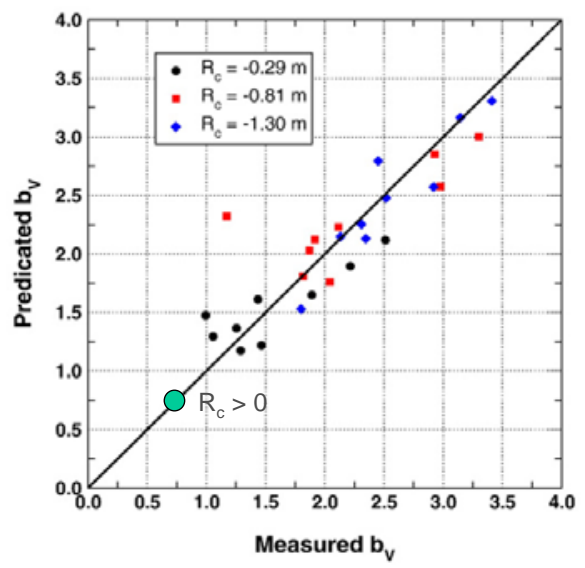

Figure 3. Shape coefficient for wave volume distributions (Fig. 12 from Hughes and Nadal, 2009) with the value of 0.75 attached.
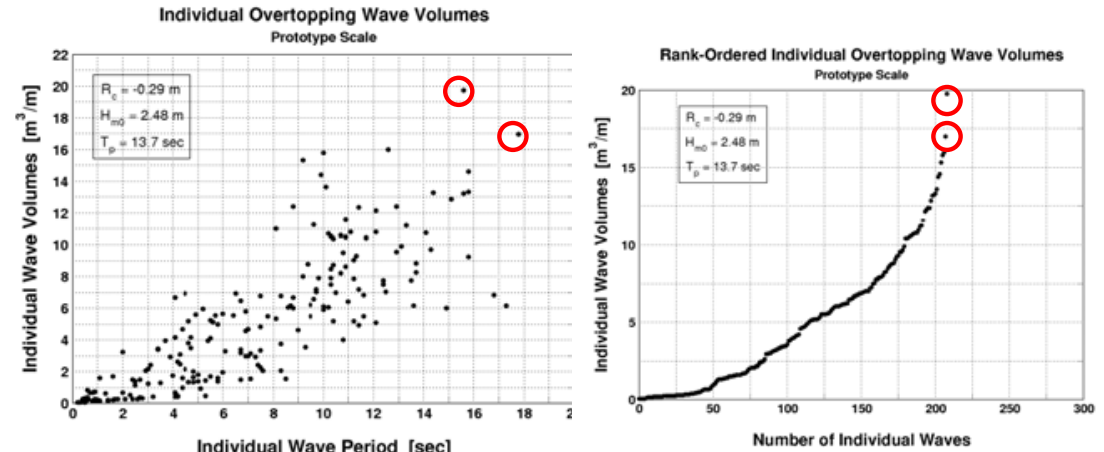

Figure 4. Wave overtopping volumes for combined overflow and overtopping (Hughes and Nadal, 2009). Wave height $\mathrm{H}_{\mathrm{m} 0}=2.48 \mathrm{~m}$.

From Figure 3 it can be concluded that if the water level comes close to the crest level, or even exceeds it, the shape factor will increase from $\mathrm{c}=0.75$. The consequence is that the maximum overtopping volume will also decrease. This conclusion can also be validated by Hughes and Nadal's (2009) test results. Figure 4 gives individual overtopping wave volumes, first versus the measured individual wave period and then as a rank-ordered distribution. Test conditions have been chosen with the lowest water level $(0.29 \mathrm{~m}$ above the crest) and with a wave heights of $2.48 \mathrm{~m}$. The wave period in all conditions was the long period of $14 \mathrm{~s}$. The mean discharge was $700 \mathrm{l} / \mathrm{s}$ per $\mathrm{m}$, far beyond the required conditions for testing at CSU. 
Red circles give the maximum values. In all Hughes and Nadal's tests, with conditions far beyond the conditions required for testing at CSU, maximum wave overtopping volumes exceed the volume of $14 \mathrm{~m}^{3} / \mathrm{m}$ only 8 times, where the absolute maximum is $20 \mathrm{~m}^{3} / \mathrm{m}$, followed by 3 maxima of $18 \mathrm{~m}^{3} / \mathrm{m}$. These maxima are lower than the calculated ones in Figure 2.

From above analysis it is clear that if the water level approaches the crest and wave overtopping becomes very large, it is likely that the assumed distribution of overtopping wave volumes with a shape factor of 0.75 is not valid any longer. But it is unknown when this deviation will start. As the Wave Overtopping Simulator should simulate real wave overtopping conditions, these conditions (the actual distribution of overtopping waves) should be known. It would possibly limit the maximum overtopping volumes to volumes that can indeed by simulated by a practical size of Wave Overtopping Simulator. For that reason it is strongly recommended to perform tests on wave overtopping, comparable to Hughes and Nadal (2009), but now with a lower water level, still fairly close to the crest. These tests would validate the decision to limit the size of the US Wave Overtopping Simulator to about $17 \mathrm{~m}^{3} / \mathrm{m}$, as described in the next Sections.

\section{Discrepancy in equations}

In Van der Meer et al. (2010) it was concluded that present knowledge and prediction formulae for flow velocity, flow depth and flow duration do not yet give consistent answers. More research is required to solve this discrepancy.

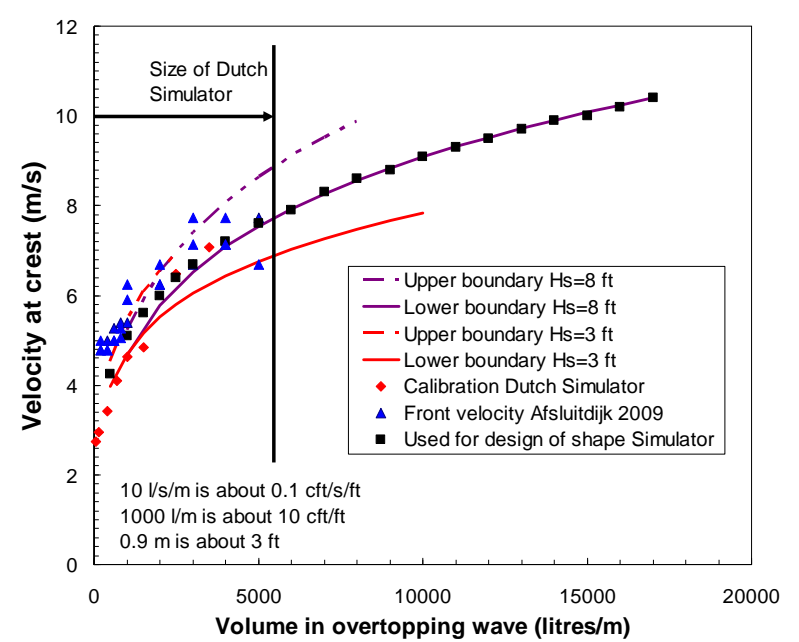

Figure 5. Proposed flow velocity versus measurements with the Dutch Simulator.

For the same overtopping wave volume lower flow velocities and flow depths are found if the overtopping discharge increases. And the same happens for the flow duration. This is physically not possible as a decrease in flow velocity should result in an increase in flow depth or flow duration (mass balance). 
For this reason an average was sought for design of the US Simulator, see Fig. 5. Measured data points have been added, which were established by the Dutch Simulator. This Simulator is limited to a size of $5.5 \mathrm{~m}^{3} / \mathrm{m}$, about one-third of the US Simulator. The red points give the data points during design and calibration of the Dutch Simulator, the blue triangles give measured points on a landward slope of 1:3. The data fall more or less around the proposed mean curve.

\section{DESIGN}

Distributions of overtopping wave volumes were calculated for the two wave conditions and up to a freeboard with $200 \mathrm{l} / \mathrm{s}$ per m overtopping discharge. Based on these calculations it was decided to build a capacity of $17 \mathrm{~m}^{3} / \mathrm{m}$, about three times larger than the Dutch Simulator $\left(5.5 \mathrm{~m}^{3} / \mathrm{m}\right)$. Most overtopping volumes will be much smaller than the maximum capacity. It was for this reason that the Simulator was designed with an inner box and an outer box, see Figure 6, where the inner box is more or less similar to the "proven concept" of the Dutch Simulator. Only when a larger volume is required than the capacity of the inner box, the outer box will be filled. Side valves enable the outflow of water from this outer box through the butterfly valve of the inner box.

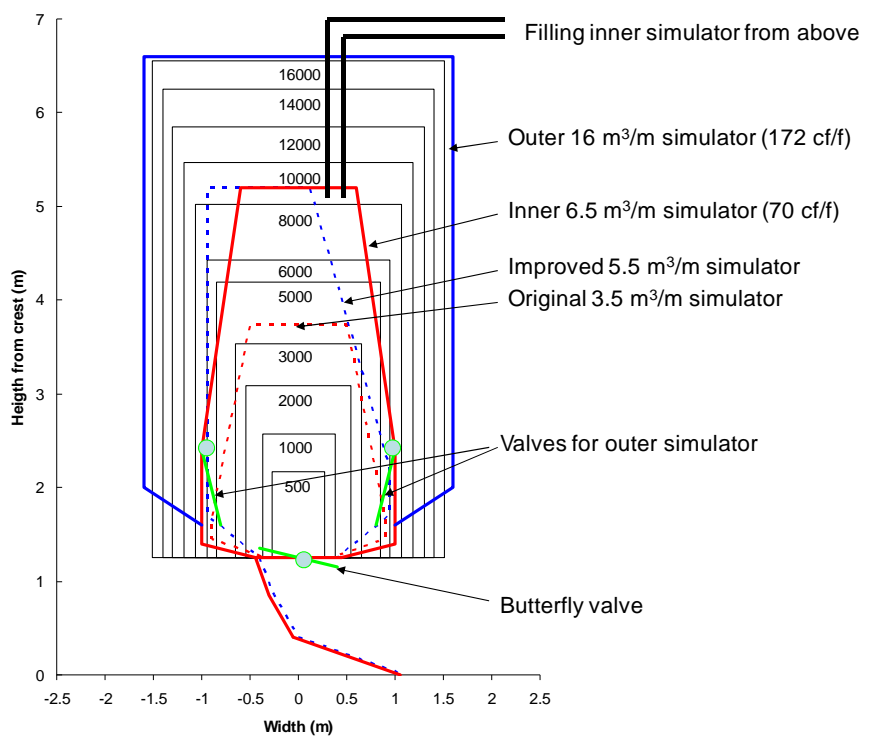

Figure 6. Cross-section of Simulator

The Wave Overtopping Simulator is not more than a box with a special shape that is constantly filled with water (the constant required average overtopping discharge), a butterfly valve that is opened at prescribed times to release all the water in the box, and a transition from valve opening to a horizontal flow of water at the crest of a levee. 
The shape of the box depends on the flow velocities required at the crest of the levee. The pressure height above the valve determines the flow velocity at the valve (Bernoulli). As first approximation of the velocity at the valve the following equation can be used:

$$
u=\sqrt{2 g x}
$$

where $\mathrm{x}=$ the pressure height. Given the overtopping volumes and required velocities at the crest, the required pressure height and corresponding average width of the box can be calculated and are given in Fig. 6.

The velocities have been calculated directly at the crest. In reality space is required for a transition slope in order to change the direction of the velocity from vertical to horizontal. For this reason the valve will be a certain distance above the crest of the dike. Certainly small volumes will increase in velocity from valve opening to the crest due to gravity. Larger volumes may have more friction at the opening.

The Simulator will be filled from above, directly into the inner Simulator. If a larger volume than $6 \mathrm{~m}^{3} / \mathrm{m}$ is required, the inner Simulator will overflow and fill the outer Simulator as well, till the required volume. All the water will be released through the butterfly valve at the inner Simulator. The size of this valve has been enlarged to a net opening of $1.0 \mathrm{~m}$.

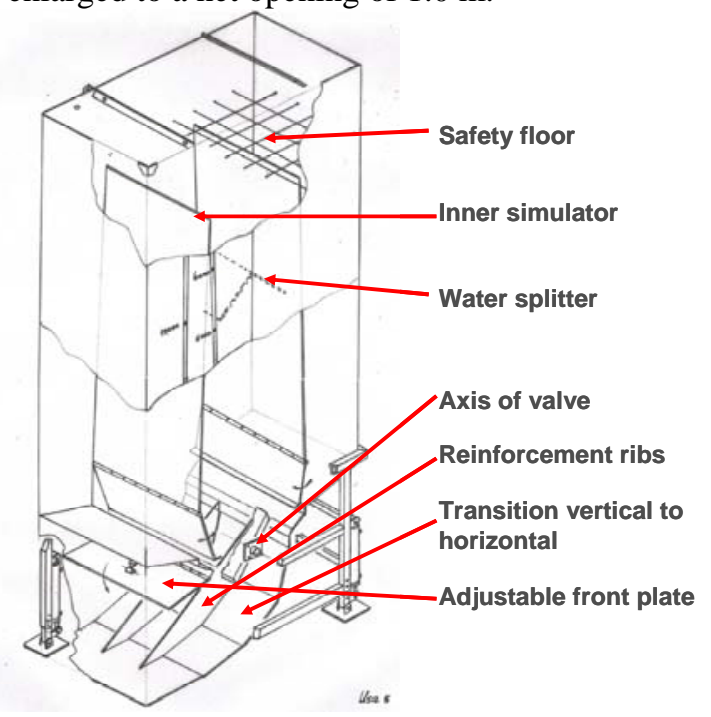

Figure 7. 3D-sketch of the US Simulator.

Figure 7 shows a 3D-sketch of the Simulator. It shows the inner and outer Simulator and the integrated platform with adjustable legs and the transition slope. A safety floor has been designed, as well as a measure ("water splitter") to prevent falling water damaging the valve. Figures 8 and 9 give an overview of the Wave Overtopping Simulator 

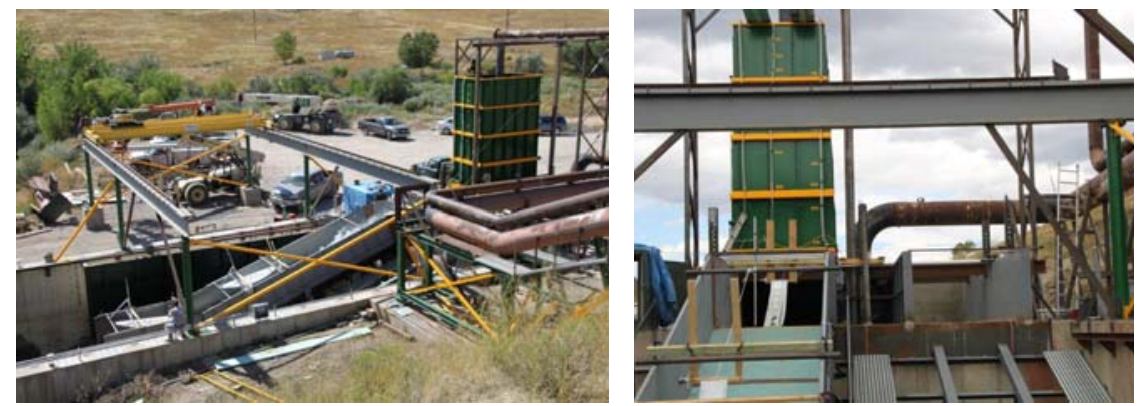

Figure 8. Overview and front view with spare flume location on the right side
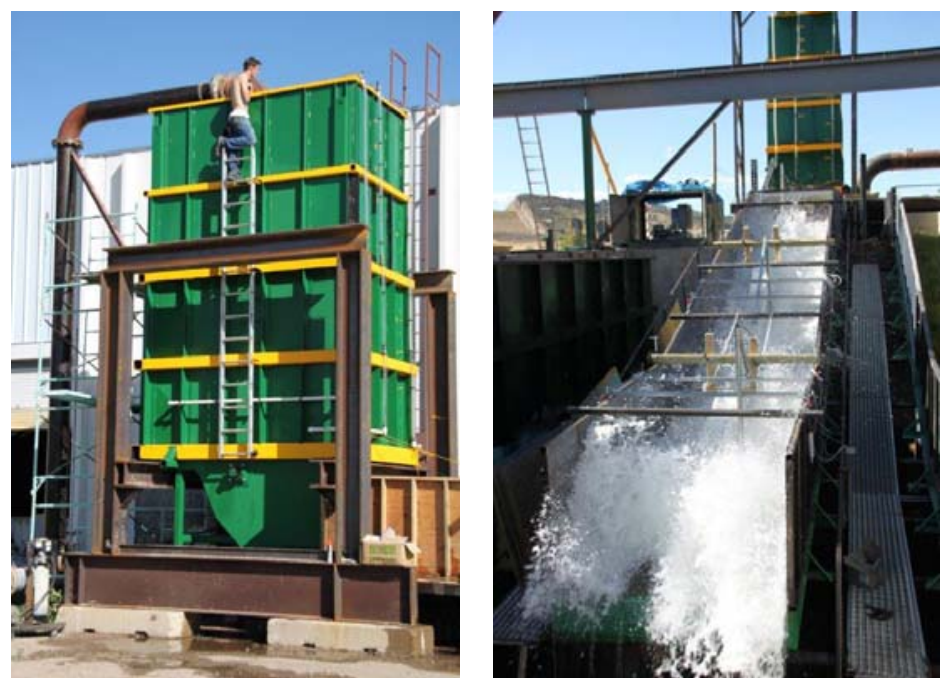

Figure 9. Impression from the side and down the flume releasing a large wave.

\section{CALIBRATION AND OPERATION OF THE SIMULATOR}

The opening of the valve should be part of the steering system in order to simulate short (6 s) as well as long (14 s) waves. It should not open too much for small volumes and also not for required long wave periods. The valve opening should be made adjustable to a maximum opening, according to the required length or overtopping duration of the overtopping wave, $\mathrm{T}_{\mathrm{ovt}}$.

An encoder has been placed on the axis of the valve, which is able to measure the rotation of the valve. Then the maximum required rotation can be part of the steering file: first a signal is given to open the valve, but when it reaches a predetermined rotation, the valve should stay there, until it gets its final signal to close the valve.

The relationship between released volume, flow thickness, flow velocity, flow duration and opening of the valve (rotation in degrees) was established during a 
calibration period. The flow depth, flow velocity and overtopping duration were measured by the system of the Dutch Simulator, see Van der Meer et al., 2010. A specific surfboard was made for the US Simulator, but the system for measuring rotations of the surfboard and the paddle wheel for measuring velocities were brought from the Netherlands, as well as the data acquisition system.

The calibration procedure consisted of releasing various wave volumes with different rotations of the valve. The maximum rotation of the valve was 62 degrees. Smaller volumes were filled with a smaller discharge than larger volumes. But the filling discharge was also varied for similar volumes. Each combination of overtopping wave volume and rotation was repeated twice. The following calibration conditions were performed.

$\begin{array}{lcl}\begin{array}{l}\text { Volumes } \\ \left(\mathrm{m}^{3} / \mathrm{m}\right)\end{array} & \begin{array}{l}\text { Filling discharges } \\ (\mathrm{l} / \mathrm{s} \text { per } \mathrm{m})\end{array} & \begin{array}{l}\text { Rotations } \\ (\text { degr })\end{array} \\ 0.2 ; 0.4 ; 0.6 ; 0.8 ; 1 & 30 & 5 ; 10 ; 15 ; 20 ; 25 ; 30 \\ 1.5 ; 2 ; 3 & 80 ; 30 & 5 ; 10 ; 15 ; 20 ; 25 ; 30 ; 35 ; 40 ; 50 ; 62 \\ 4 ; 5 ; 6 ; 7 & 150 ; 50 & 5 ; 10 ; 15 ; 20 ; 25 ; 30 ; 35 ; 40 ; 50 ; 62 \\ 9 ; 11 ; 13 ; 15 & 250 ; 100 & 10 ; 15 ; 20 ; 25 ; 30 ; 35 ; 40 ; 45 ; 50 ; 55 ; 62\end{array}$

The first step in the analysis was to make a graph for each overtopping wave volume with overtopping duration $\mathrm{T}_{\text {ovt }}$ as a function of the applied rotation. Figure 10 gives as and example a middle sized volume of $7 \mathrm{~m}^{3} / \mathrm{m}(70 \mathrm{ft} / \mathrm{ft}$, which is still more than the maximum size of the Dutch Simulator).

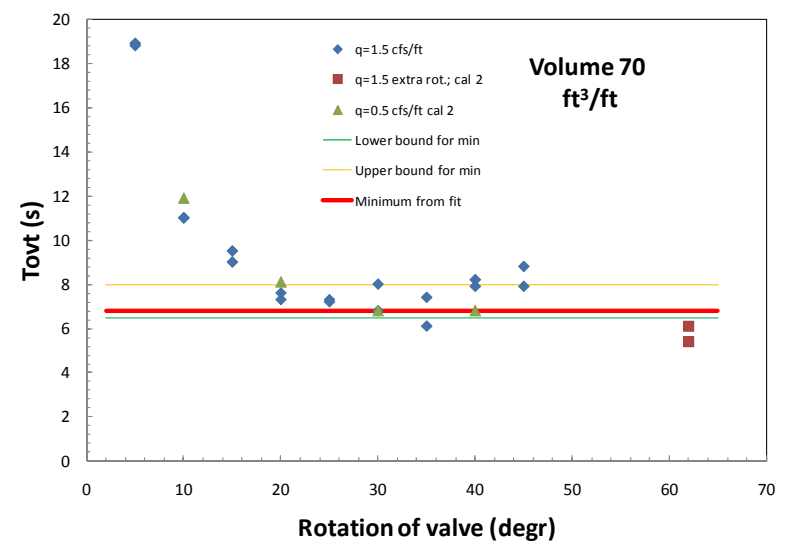

Figure 10. Overtopping duration versus opening of the valve for a volume of $7 \mathrm{~m}^{3} / \mathrm{m}$.

Although there is scatter, the trend is clear that if the rotation of the valve is large enough, the overtopping durations will be more or less similar (in Figure 10 larger than 20-25 degrees. This is of course logical. If the valve is open enough to avoid obstruction, then similar overtopping durations may be obtained. It is also clear that if the rotation is small enough, the overtopping 
durations will increase. They increase more for the larger volumes. The effect of the rotation is specifically noticed for larger rotations and larger volumes.

Each volume has a minimum overtopping duration, $\mathrm{T}_{\text {ovt min }}$, if the rotation is large enough. This is given by a horizontal line in the right part of Figure 10. There is a certain rotation, Rot $_{\text {min }}$, where for larger values the minimum overtopping duration is found and for smaller values the overtopping duration will increase (the upward trend of the data on the left side of the graph).

The final analysis resulted in a system where for a given overtopping discharge, overtopping wave volume and required overtopping duration, the maximum rotation of the valve can be calculated. Figure 11 gives a graphical overview, together with possible overtopping durations for peak periods of 6 and 9 s, respectively (the $14 \mathrm{~s}$ wave was changed later to $9 \mathrm{~s}$ ).

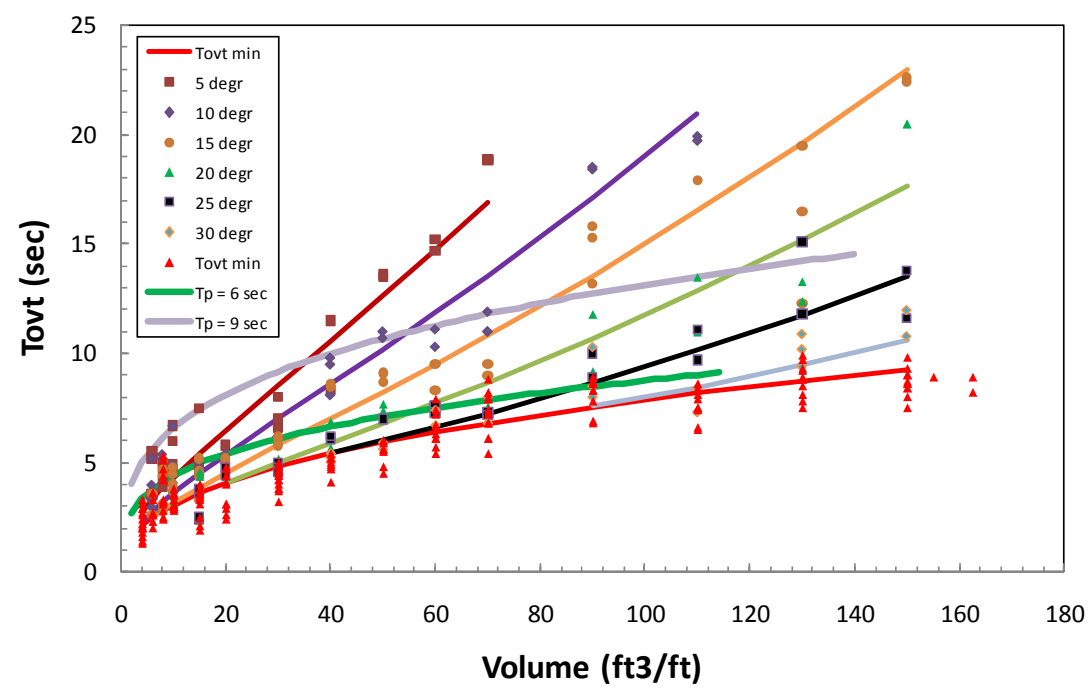

Figure 11. Final results of the calibration: Rotation of valve as function of overtopping wave volume and required overtopping time.

The minimum overtopping duration, $\mathrm{T}_{\text {ovt min }}$, is reached when the rotation of the valve is wide enough. Smaller overtopping durations cannot be simulated. The minimum overtopping duration is shown by the lowest line in Fig. 11 and is given by (imperial units):

$$
\mathrm{T}_{\text {ovt min }}=1.19 \mathrm{~V}^{0.41}
$$

The minimum overtopping duration is reached when the rotation of the valve is at least equal or larger than the minimum rotation (imperial units):

$$
\operatorname{Rot}_{\text {min }}=10 \mathrm{~V}^{0.25}
$$

If the required overtopping duration is larger than $\mathrm{T}_{\mathrm{ovt} \text { min }}$ the required rotation of the valve can be calculated by (imperial units):

$$
\text { Rot }=\operatorname{Rot}_{\text {min }}-\left[\left(\mathrm{T}_{\text {ovt }}-\mathrm{T}_{\text {ovt min }}\right) / \mathrm{a}\right]^{1 / 1.7}
$$


with: $\mathrm{a}=0.00048 \mathrm{~V}+0.012$

These are the up-going curves in Fig. 11. Above equations were built into the steering system. Two relationships have been given in Fig. 11 for assumed overtopping durations versus overtopping volumes. A wave condition with a peak period of $9 \mathrm{~s}$ will have longer overtopping durations than with $6 \mathrm{~s}$. Assume that for the $9 \mathrm{~s}$ peak period wave an overtopping volume of $8 \mathrm{~m}^{3} / \mathrm{m}$ $\left(80 \mathrm{ft}^{3} / \mathrm{ft}\right)$ has to be simulated, then the rotation of the valve has to be 15 degrees in order to get a required overtopping duration of $11.5 \mathrm{~s}$.

\section{CONCLUSIONS}

It was possible to design and construct a large, $17 \mathrm{~m}^{3} / \mathrm{m}$, Wave Overtopping Simulator with the capability of simulating overtopping discharges beyond $200 \mathrm{l} / \mathrm{s}$ per $\mathrm{m}$. The steering of the butterfly valve to a pre-calculated opening makes it possible to simulate $6 \mathrm{~s}$ waves as well as $14 \mathrm{~s}$ waves. Results of first testing have been described in Thornton et al., 2011.

\section{ACKNOWLEDGEMENTS}

The development of the new overtopping simulator was funded by Task Force Hope, New Orleans District, U..S. Army Corps of Engineers. Permission was granted by Task Force Hope to publish this information.

\section{REFERENCES}

Hughes, S.A. and N.C. Nadal, 2009. Laboratory study of combined wave overtopping and storm surge overflow of a levee. J. of Coastal Engineering 56 (2009) 244-259.

Overtopping Manual, 2007. EurOtop; Wave Overtopping of Sea Defences and Related Structures Assessment Manual. UK: N.W.H. Allsop, T. Pullen, T. Bruce. NL: J.W. van der Meer. DE: H. Schüttrumpf, A. Kortenhaus. www.overtopping-manual.com.

Steendam, G.J., J.W. van der Meer, B. Hardeman and A. van Hoven, 2010. Destructive wave overtopping tests on grass covered landward slopes of dikes and transitions to berms. ASCE, Proc. ICCE 2010, Shanghai.

Thornton, C., J.W. van der Meer and S.A. Hughes, 2011. Testing levee slope resiliency at the new Colorado State University Wave Overtopping Test Facility. Proc. Coastal Structures 2011, Japan.

Van der Meer, J.W., B. Hardeman, G.J. Steendam, H. Schttrumpf and H. Verheij, 2010. Flow depths and velocities at crest and inner slope of a dike, in theory and with theWave Overtopping Simulator. ASCE, Proc. ICCE 2010, Shanghai.

Van der Meer, J.W., R. Schrijver, B. Hardeman, A. van Hoven, H. Verheij and G.J. Steendam, 2009. Guidance on erosion resistance of inner slopes of dikes from three years of testing with the Wave Overtopping Simulator. Proc. ICE, Coasts, Marine Structures and Breakwaters 2009, Edinburgh, UK. 
KEYWORDS - CSt2011

Abstract acceptance number 0042

DESIGN AND OPERATION OF THE US WAVE OVERTOPPING SIMULATOR

$1^{\text {st }}$ Author: Van der Meer, Jentsje Wouter

$2^{\text {nd }}$ Author: Thornton, Christopher

$3^{\text {rd }}$ Author: Hughes, Steven A.

Wave Overtopping Simulator

Wave Overtopping

Levees

Grass erosion 